\section{ASSOCIATION OF SPECIAL LIBRARIES AND INFORMATION BUREAUX}

\section{SEVENTEENTH ANNUAL CONFERENCE}

\section{$\mathrm{T}$}

HE sixteenth annual conference of ASLIB (Association of Special Libraries and Information Bureaux) was planned to be held at University College, Nottingham, in mid-September 1939, but had to be cancelled owing to the outbreak of hostilities; the papers which were prepared for that Conference were afterwards published. The previous Conference had been held at Oxford in 1938 during the Munich crisis. Any idea of holding a succeeding conference in 1940 was rudely shattered by the Battle of Britain, but the comparative lull in the autumn of 1941 encouraged ASLIB to embark on the project of resuming its annual conference in 1942, with the limitation that the principal meeting should be held in London, and the papers there read and discussed should be available for subsequent local meetings in various provincial centres.

The decision to hold the London Conference proved to be very happy, and the generosity of the Royal Society in providing accommodation for the meetings and other functions greatly contributed to the successful outcome. In all, 137 members of ASLIB and visitors attended the several sessions, which occupied the afternoon and evening of November 7 and the morning and afternoon of November 8, and were preceded on the morning of November 7 by the annual general meeting of the Association.

At this meeting, Prof. R. S. Hutton, Goldsmiths professor of metallurgy, Cambridge, was elected president for the ensuing year, in succession to Sir Harry Lindsay, who had served since November 1939. Mr. Theodore Besterman was elected honorary secretary in succession to Mr. Edward Carter, and Mr. E. Lancaster-Jones was re-elected honorary treasurer. At a later meeting of the council, Messrs. Carter and Lancaster-Jones were re-elected respectively chairman and vice-chairman of the council.

The Conference opened at noon on Saturday with a characteristically stimulating address on international systems and standards given by Sir Richard Gregory. The main part of Sir Richard's address is printed elsewhere in this issue (p. 62\%).

At the first session of the Conference proper, under the chairmanship of Prof. A. C. Egerton, two papers dealing with training in the use of libraries were presented by Mr. C. H. C. Osborne, honorary secretary of the School Libraries Section of the Library Association, and Prof. R. S. Hutton respectively. The former dealt with school and the latter with university libraries, and each indicated the extent to which instruction in the methodology of libraries might be imparted, with mutual benefit to the library and its user. Comparisons of conditions in Great Britain with the practice in other countries, especially in the United States, was deprecated by some speakers in the subsequent discussion, on the grounds that conditions were not comparable. Nevertheless, the feeling was general that more could be done by librarians and educational authorities to educate those who would ultimately have to depend largely upon reference literature in the technique of extracting it from the vast resources of modern libraries.

At the second session, on the evening of November 7, Dr. Luxmore Newcombe, of the National Central
Library, took the chair and the audience listened with avidity to Mr. Besterman's demand for a "Union List of Periodicals in British Libraries". In his customary blend of dogmatic confidence that difificulties were merely so many bubbles to be pricked and experienced skill in deflecting the anticipated missiles of more substantial composition, Mr. Besterman carried his hearers into a calm and purposeful realm of accomplished fact. One had the distinct impression that the Union Catalogue was as good as in one's hands, and some of us who have experienced the tenacity with which its proponent pursues an objective on which he has set his mind had the uneasy conviction that in due course we should be involved in the usual mass of collation attendant upon the production of all Union Catalogues.

Nevertheless, we shall be willing victims, for all of us realize that these monumental contrivances are essential to the ultimate objective of planned economy and efficiency in our national resources of vital reference periodicals. The two editions of the "World List of Scientific Periodicals" have done a great deal in the period intervening between the two World Wars to enable Great Britain to build up its resources, particularly of the more obscure foreign scientific and technical periodicals. Much remains to be done, but all previous Union Catalogues and lists have largely ignored the wealth of reference material that now exists in the various special libraries.

A paper on "Agriculture and the War Stimulus" by Mr. C. S. Orwin, director of the Agricultural Economics Research Institute, had to be taken as read in the absence of its author or any suitable substitute for him.

At the third session, on the morning of November 8, Colonel E. E. B. Mackintosh, director and secretary of the Science Museum, took the chair for a symposium on microfilms, which attracted a very appreciative audience. Mrs. Lucia Moholy, director of the Aslib Microfilm Service, sketched the early uses of microphotography for communication of information in war-time and proceeded to describe the evolution and functions of the Aslib Microfilm Service in the present emergency. To a considerable extent the Service is occupied in photographing on microfilm current issues of foreign scientific and technical periodicals that emanate from enemy or enemycontrolled countries and are received in very small quantities in Great Britain. The microfilms are used to provide additional copies of the whole issues or excerpts therefrom, as required by individuals or institutions having no access to the originals, or desiring their own copies. The necessity for the provision of reading apparatus to enlarge the microfilms to legible dimensions was stressed, as the supply at present available in Great Britain is wholly inadequate.

Mrs. Moholy's interesting paper was followed by one by Mr. E. Lancaster-Jones, keeper of the Science Library, in which the attributes of the microfilm copy of a normal reference book or volume of a periodical, as compared with the original, received detailed consideration. The possibilities of supplementing the microfilm copy by various guides in order to adapt it to facile use by the staff and clients of a reference library were sketched. A further paper by Dr. Vernon Tate, of the National Archives, Washington, D.C., had been promised for this symposium, but was unavoidably delayed in transit. As Dr. Tate's experience of microfilm technique is profound, this was a great disappointment. 
In the subsequent discussion on the two papers, many helpful remarks were made upon the provision of reading apparatus by the adaptation of available mechanisms, such as cinema projectors, to the purpose, and there is no doubt that those individuals who possess the skill and equipment to carry out the minor constructional modifications needed can produce a reasonably efficient machine for enlarging the films, certainly for the purposes of individual research. But one has only to handle an efficient commercial reader, specially designed for the work, to realize that its construction is the result of long experience of the problem, and the results are very satisfying. A small exhibition of reading apparatus, arranged by the Aslib Microfilm Service, proved very popular and instructive.

The final session of the Conference, under the chairmanship of Mr. T. R. Dawson, of the Research Association of British Rubber Manufacturers, was devoted to a paper by Mr. J. E. Wright of the Post Office Research Station on "Some Methods used in the Special Library of a Research Department", followed by one on "War-time Books and Periodicals": some Suggestions", by Mr. B. M. Headicar. Mr. Wright's paper was not merely an account of the methodology of the particular library of the Post Office Research Station, but also contained a rich fund of information and suggestions adapted to use by any similar library; a series of clues to specific requests for information was perhaps the most interesting and instructive section of the paper. Mr. Headicar dealt in his customary adept manner with a multiplicity of practical details, including suggestions for economy in paper and binding; he illustrated his address by greatly appreciated practical demonstrations of the methods recommended.

\section{SEASONING OF TIMBER}

\section{BY ALEXANDER L. HOWARD}

Necessitas non habet legem ("Piers Plowman", 1377).

W HILE it is true that the harsh dictates of necessity have resulted in many discoveries and useful practices in the seasoning of timber, laws regarding the process are adamant; and although simple, the principles which govern the procedure are unalterable. The sap and moisture contents must be drawn out of the wood and the necessary methods employed to bring the wood to that degree of moisture content desired. The process must be varied according to the species of timber and the purpose for which it is required.

Never in the history of Great Britain has this question been of such vital importance as it is to-day. Commodities of all sorts-food, delicate instruments, ammunition, and war material of all kinds-must be packed safely for transport over great distances and under trying conditions, and it is essential that the cases used for this purpose can be relied upon to preserve their valuable contents.

Of those materials which can be used, timber plays the most important part. We are forced to rely to a very great extent upon available native timber, which could be put to better use if adequate facilities for seasoning existed.

It has been proved that timber of many kinds, and in the dimensions required, can be seasoned in a satisfactory manner in a short time, and indeed there are already many established kilns fully occupied and successfully working, but in no sense sufficient for the demands of total war. Even though it involves great expense and effort, many more drying kilns of efficient design should be established as quickly as possible to make good this deficiency.

Fortunately, the lessons of the War of 1914-18 and scientific research have enabled us to overcome all the main difficulties, and the chief problem that concerns us is no longer the method to be employed, but the establishment of sufficient kilns throughout the country.

The primary object is to create within the kiln a continuous and regular current of air (at first charged with moisture) to suit the condition of the unseasoned or fractious wood, and then to withdraw the moisture and introduce the heat by carefully controlled degrees, until the desired percentage of moisture contents has been acquired. To accomplish this, it is essential that every square inch of the timber should be sub. jected to an equal volume of the current, and while the dimensions of the kiln play an important part, by far the greater importance lies in the scientific application of the correct combination of moisture and heat.

During the course of the last hundred years, innumerable processes have been tried out, many of which have been patented but later abandoned. Among these systems is a process which might be described as a 'bakery' - that is, one in which the timber is placed in a compartment somewhat similar to an oven. Other ingenious systems have been tried, in which the wood is subjected to a vacuum, with water and steam introduced later. Another process has been to place the timber in boiling water accompanied by the introduction of saccharine or other ingredient, and a still further attempt has been made by the use of an electric current. Most of these, or perhaps all, have been abandoned, at least so far as commercial practice is concerned: at another time, and in more easy circumstances, it would be desirable to enter into further scientific research, which might give us more information and thus secure even better results. At present our endeavour should be to concentrate our attention towards providing that which we know can secure an immediate as well as a satisfactory result.

'Two methods are available, which are what are known as the 'progressive' and the 'compartment' kilns, both well understood and universally accepted.

For large quantities of box boards the progressive method would probably be efficient, but this system would not succeed when applied to the more fractious and difficult woods, when the compartment system should be adopted.

In the progressive kiln the wood is placed on trucks, allowing sufficient air space between the boards. The trucks are moved under control through successive chambers which have been prepared with the necessary saturation of moisture and the introduction of dry heat. The moisture contents are gradually withdrawn and the dry heat increased. On completion, the charge is found to contain that correct percentage of moisture contents which was calculated as ordered.

In the compartment system, as the name implies, the timber is piled with similar air ventilation, but in a fixed chamber where moisture and heat are introduced. As in the case of the progressive kiln, the moisture is gradually withdrawn and the heat 